vom 4. Tag an geringer; das vorübergehende Maximum am 5. Tag ist weniger stark ausgeprägt.

Die Fluorazetat-Hemmung (Fig. $1 B$ ) verläuft in den ersten 5 Tagen nach der Infektion ähnlich. Auch hier ist die Hemmung anfangs bei schwach belichteten Pflanzen stärker als bei gut belichteten, sinkt dann jedoch stärker ab. Nach Belichtung mit 7000 Lux durchläuft die Fluorazetat-Hemmung ein Minimum am 3. Tag und steigt dann wieder auf den Ausgangswert an. Nach Belichtung mit 3000 Lux liegt das stärker ausgeprägte Minimum am 4. Tag nach der Infektion; am 5. Tag ist die Hemmung bei schwach belichteten Pflanzen deutlich stärker ausgeprägt als bei gut belichteten. Die Verzögerung des Minimums entspricht einer ähnlichen Verspätung der Sporulation von Puccinia auf den leicht etiolierten Blättern unterbelichteter Pflanzen, welche ohne Änderung des Befallstyps weniger Sporen erzeugten.

Die Ergebnisse geben weitere Hinweise dafür, daß während der Inkubationszeit obligater Parasiten die Aktivität von Fermentsystemen in verschiedenen Phasen unterschiedlich verändert wird [vgl. hierzu $\left.\left.\left.\left.{ }^{1}\right),{ }^{4}\right),{ }^{5}\right)\right]$. Eine eingehende Erörterung der Befunde im Zusammenhang mit der Zerlegung des Dyssymbioseverlaufs in physiologisch unterschiedliche Phasen soll an anderer Stelle erfolgen. Hier sei nur mit Nachdruck darauf hingewiesen, daß die absolute Größe der Hemmwirkung wie ihre Veränderung im Laufe des Infektionsprozesses in beträchtlichem Maße von der Belichtung abhängt. Die Berücksichtigung dieses Faktors dürfte der Auflklärung widerspruchsvoller Angaben dienen.

Institut für Pflanzenpathologie und Pflanzenschutz der Universität, Göttingen

W. H. Furchs u. Renate Stebert

Eingegangen am 22, November 1958

*) Die Quecksilberdampf-Hochdrucklampen mit Leuchtstof (H RL 250 W und HRL 400 W) der Radium Elektrizitäts-Gesellschaft m.b.H., Wipperfürth, kombiniert mit den Radalreflektoren und den dazugehörigen Domen der Firma Ernst Rademacher G.m.b.H., Düsseldorf, ermöglichten die Durchführung der Versuche in den Wintermonaten.

1) Farkas, G. L.: Acta biol. 7, 315 (1957). - 2) Farkas, G. L. u. Kiraly: Z, physiol. Plantarum 8, 877 (1955). - " ${ }^{3}$ Heitefuss, R.: Diss. Göttingen 1957. - 4) SEMPIO, C.: Phytopathology 40, 799 (1950). - 5) Shaw, M., u. A. R. Hawkins: Canad. J. Bot. 36, (1958).

\section{A New Object for Studying the Structure of the Living Nucleus}

The various aspects of the structure of the quiescent nucleus have been studied by many investigators [for details see $\left.\left.\left.^{1}\right),{ }^{3-5}\right)\right]$. Examining the superior epidermis of the bulb

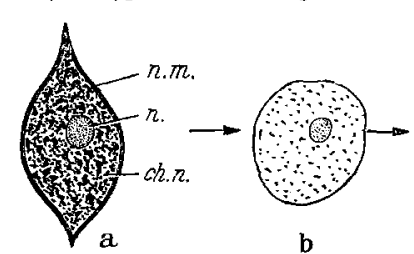
scales of the snowdrop $(\mathrm{Ga}$ lanthus nivalis) in the flower ing period, I have discovered a new object suitable for studying the structure of the living nucleus in the light field and phase contrast microscopy.

The nucleus of the epidermal cells of the snowdrop is very clearly outlined even when examined with an ordinary microscope. This fact is possible because the refraction index of the nucleus of the snowdrop is different from that of the environment. The shape of the nucleus as a rule is ovoid or ovoid-fusiform, and more seldom fusiform. The two ends of the nucleus are usually lengthened, they be come thin and filiform. As a rule in the cell the nucleus is in an oblique posi-

Fig. 1. The nucleus from the superior epidermal cells of the snowdrop (Galanthus nivalis): a the membrane, $n=$ nucleolus, chromatin network formed chromatin granules; $b$ the nucleus

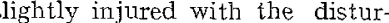
bed structure; $c$ the nucleus trongly injured without structure; $d$ the dead nucleus

tion compared with the longitudinal walls. Its dimensions are the following: the length 20 to $28 \mu$, the breadth 10 to $12 \mu$.

When looking at this nucleus with an objective having a middle power of resolution it appears structured. But the greatest number of the details of the structure of the nucleus can be seen with the immersion objective. By means of this objective I could distinguish in the nucleus of the snowdrop, even in the light field of the microcope, the nuclear membrane, 1 to 2 nucleoli and the chromatin network, consisting of chromatin granules (see Fig. 1a).

The chromatin granules appear more outlined in the phase contrast microscope. With the help of this device I could observe the shape and movements of the granules. They are commonly spherical or ovoid, at other times they are lengthened like a short stick or have the shape of the letter V. Lons and attentive observations led me to the conclusion that in the living nucleus the granules are not motionless. As a rule they are found in a constant, but hardly perceptible oscillation. Their slight movements have the characteristic of a. periodic vibration. Sometimes during these vibrations a slight irreversible transference of the granules can take place. The consequence of this fact is the very slow modification of the general configuration of the structure of the living nucleus. Such movements have also been described by GaIDUKov ${ }^{2}$ with regard to the nucleus of the stamineal hair cells of Tradescantia virginica, but without an ulterior confirmation.

Besides the study of the living structure, the nucleus of the snowdrop is also a suitable object for the observation of the traumatic actions. As a result of a slight injury of the cells it loses its ovoid-fusiform shape and becomes spherical. The structure of the nucleus at this stage cannot be observed in the light field of the microscope. But with the help of a phase contrast microscope anyone can see that the chromatin granules have not completely disappeared (Fig. 1b). By a stronger injury of the cells, the nucleus loses completely its structure and becomes homogeneous even in the phase contrast microscope (Fig. 1 c). The dead nucleus (Fig. $1 \mathrm{~d}$ ) has a reduced volume being more strongly structured and apparently deprived of nucleoli.

The author is indebted to Dr. E. Pop, Prof, of Plant Physiology, Cluj/Rumania, for his suggestions.

Laboratory of Plant Physiology of the University "V. Babes," Clui (Klausenburg), Rumania P.R.

Eingegangen am 22. November 1958

VIOREL SORAN

1) Delay, C.: Rev. Cytol. et Cytophys. végét. 9, 169; 10, 103 (1949). - ${ }^{2}$ ) Gardukov, N.: Dunkelfeldbeleuchtung und Ultramikroskopie in der Biologie und Medizin. Jena 1910. - 3) KUSTER, E. Die Pflanzenzelle, 3. Aufl. Jena 1956-4) STRUGGer, S Praktikum der Zell- und Gewebephysiologie der Pflanze, 2.Aufl. Berlin-Göttingen-Heidelberg: Springer 1949. $-{ }^{5}$ ) TIschLER, G. Allgemeine Pflanzenkaryologie. In Linsbauers Handbuch der Pflanzenanatomie, 2. Aufl., Bd. II. Berlin 1934.

\section{Streckungs- und Teilungswachstum isolierter Mesophyllzellen} von Macleaya cordata (Willd.) $\mathrm{R}$. Br.

In submersen Kulturen isolierter Mesophyllzellen von Macleaya cordata (WILld.) R. Br., die auf mechanischem Wege nach den Angaben von SCHMUCKER ${ }^{1}$ ) erhalten wurden,

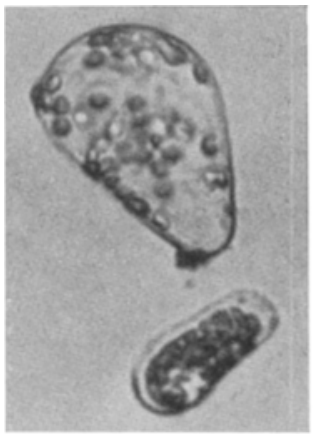

Fig. 1

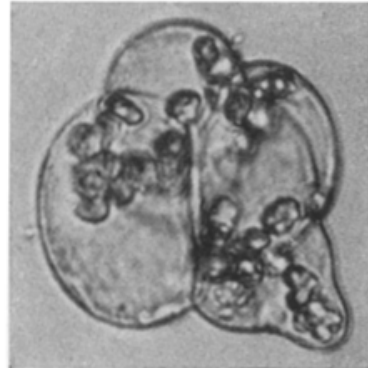

Fig. 2
Fig. 1. Zwei isolierte Palisadenzelien, von denen die untere abgestorben, die obere aber erheblich gewachsen ist. Als Vergleichsmab für das Wachstum der oberen Zelle kann die untere Zelle herangezogen werden, da deren ursprüngliche Größe nahezu unverändert is

Fig. 2. Zellverband, der durch Teilungswachstum aus einer isolierten Palisadenzelle hervorgegangen ist

Beide Aufnahmen wurden unter Verwendung eines Plankton mikroskopes nach UTERMöHL mit Periplan $25 \times$ und Achromat $16 x$ hergestellt

trat bei einem größeren Prozentsatz der isolierten Zellen in einfachen Medien mit und ohne Reibsaft'), ${ }^{2}$ ) in Überein- 